\title{
Chromosomal and morphological studies of diploid and polyploid cytotypes of Stevia rebaudiana (Bertoni) Bertoni (Eupatorieae, Asteraceae)
}

\author{
Vanessa M. de Oliveira ${ }^{1}$, Eliana R. Forni-Martins ${ }^{1}$, Pedro M. Magalhães ${ }^{2}$ and Marcos N. Alves ${ }^{2}$ \\ ${ }^{1}$ Universidade Estadual de Campinas, Instituto de Biologia, Departamento de Botânica, \\ Campinas, SP, Brazil. \\ ${ }^{2}$ Universidade Estadual de Campinas, Centro Pluridisciplinar de Pesquisas Químicas, \\ Biológicas e Agrícolas, Campinas, SP, Brazil.
}

\begin{abstract}
In this study, we examined the chromosome number and some morphological features of strains of Stevia rebaudiana. The chromosomes were analyzed during mitosis and diakinesis, and the tetrad normality and pollen viability were also assessed. In addition, stomata and pollen were measured and some plant features were studied morphometrically. All of the strains had $2 n=22$, except for two, which had $2 n=33$ and $2 n=44$. Pairing at diakinesis was $n=11_{\|}$for all of the diploid strains, whereas the triploid and tetraploid strains had $n=11_{\text {III }}$ and $n=11_{\text {IV }}$, respectively. Triploid and tetraploid plants had a lower tetrad normality rate than the diploids. All of the strains had inviable pollen. Thus, the higher the ploidy number, the greater the size of the pollen and the stomata, and the lower their number per unit area. The triploid strain produced the shortest plants and the lowest number of inflorescences, whereas the tetraploid strain had the largest leaves. Analysis of variance revealed highly significant differences among the strains, with a positive correlation between the level of ploidy and all of the morphological features examined.
\end{abstract}

Key words: Asteraceae, pollen, polyploidy, Stevia rebaudiana, stevioside, stomata.

Received: May 7, 2003; Accepted: November 27, 2003.

\section{Introduction}

The genus Stevia Cav. (Eupatorieae, Asteraceae), which consists of approximately 150-200 species of herbaceous, shrub and sub-shrub plants (Gentry, 1996), is one of the most distinctive genera within the tribe Eupatorieae, mainly because of the morphological uniformity of its flowers and capitula, which consist of five tubular flowers and five involucral bracts (King and Robinson, 1987). A1though geographically widespread, this genus occurs exclusively in tropical and subtropical regions of the United States and Central and South America (Robinson and King, 1977). Randi (1980) reviewed the potential uses of Stevia rebaudiana, which produces stevioside, a non-caloric sweetener that does not ferment in the human body.

Thirteen distinct strains of $S$. rebaudiana are currently being domesticated and assessed agronomically by the Centro Pluridisciplinar de Pesquisas Químicas, Biológicas e Agricolas (CPQBA/UNICAMP). Although this

Send correspondence to E. R. Forni-Martins. Universidade Estadual de Campinas Instituto de Biologia, Departamento de Botânica, Caixa Postal 6109, 13083-970 Campinas, SP, Brazil. E-mail: elianafm@unicamp.br. species has not yet been extensively studied agronomically, considerable genetic variability has been observed in plant size, flowering period, and stevioside content, which may vary from $2 \%$ to $10 \%$ (Magalhães, 2000).

Several of the known strains of $S$. rebaudiana resulted from an experiment done at the University of New Mexico designed to develop polyploids that were richer in stevioside (Valois, 1992). In Brazil, plants from this experiment were initially cultivated at the CENARGEN/EMBRAPA germplasm bank before part of the collection was transferred to CPQBA/UNICAMP. The induction of polyploidy to improve agronomic yields is a process commonly used in plants of economic interest (Allard, 1960) and has been applied to other species such as Nicandra physaloides (Gupta and Roy, 1986), coffee (Cruz et al., 1993), Clitoria ternatea (Ghandi and Patil, 1997) and orange (RomeroAranda et al., 1997).

A better adaptability of individuals and increased organ and cell sizes are usually associated with polyploidy (Guerra, 1988). In Andropogon gerardii, a species with hexaploid $(2 \mathrm{n}=6 \mathrm{x}=60)$ and enneaploid $(2 \mathrm{n}=9 \mathrm{x}=90)$ cytotypes, differences in plant size have been observed, and although seed production per unit area is the same in both 
cytotypes, it is more efficient in hexaploids (Keeler and Davis, 1999). In some species of coffee with different numbers of chromosomes, higher levels of ploidy generally produce larger stomatal cells with a greater number of chloroplasts (Boaventura et al., 1981).

In Gramineae such as Paspalum, diploid and tetraploid races within a species are basically distinguished by their reproductive system, which is sexual in diploids and apomictic in polyploids (Burson, 1975). Crossbreeding between individuals with different numbers of chromosomes usually leads to sterile progeny. According to Allard (1960), in various agricultural plants with diploid and tetraploid individuals, the progeny are partially or completely sterile triploids that do not bear seeds.

The main objective of this study was to determine the chromosome numbers of the strains of $S$. rebaudiana cultivated at CPQBA/UNICAMP in order to obtain information that could be useful in breeding programs. The tetrad normality and pollen viability were used to estimate the regularity of meiosis. Some morphological features of each strain were also analyzed morphometrically in order to asses the relationship with the level of ploidy.

\section{Material and Methods}

The plant material (floral buds, achenes and roots) for the cytogenetic studies was collected from strains of $S$. rebaudiana cultivated in vivo or in vitro at CPQBA/UNICAMP. These strains were obtained mainly from CENARGEN/EMBRAPA, in Brasília (Table 1), and originally derived from experiments by Valois (1992), who exposed seeds of $S$. rebaudiana to nine treatments by soaking them for $18 \mathrm{~h}$ in a solution of colchicine (an antimitotic agent), the concentration of which ranged from $0.5 \%$ (treatment T1) to $0.001 \%$ (treatment T9). A control treatment with no colchicine (T0) was also done. After the treatment, all of the seeds were kept under conditions appropriate for germination.
In this study, the original designations of Valois (1992) for the plants resulting from each treatment have been maintained: the letter $\mathrm{T}$ followed by a number refers to the concentration of colchicine used and the letter $\mathrm{V}$ followed by a number identifies each vase (Table 1). Voucher specimens of each strain cultivated in the field were deposited in the herbarium at UEC (Universidade Estadual de Campinas) (Table 1).

\section{Mitotic and meiotic studies}

For the mitotic studies, root tips were obtained from plants cultivated in vitro or from dark achenes germinated in gerbox with gibberellic acid (50 ppm), at room temperature. Light achenes are sterile (Felippe et al., 1971; Monteiro, 1980). The root tips were pretreated with paradichlorobenzene (PDB) for $4 \mathrm{~h}$ at $16{ }^{\circ} \mathrm{C}-18{ }^{\circ} \mathrm{C}$ and fixed in ethanol-acetic acid $(3: 1, \mathrm{v} / \mathrm{v})$. Cytological preparations were obtained using the Giemsa technique (Guerra, 1983). For meiotic analysis, floral buds were fixed in ethanol-acetic acid $(3: 1, \mathrm{v} / \mathrm{v})$ for approximately $24 \mathrm{~h}$ and the anthers then squashed onto slides in acetic carmine (Medina and Conagin, 1964).

The cytological preparations were examined by light microscopy. All cells in which it was possible to determine the chromosome number, the meiotic behavior and morphological features, were included in the analysis. Chromosome numbers were based on counts from an average of 10 cells per strain. The karyotypes were determined from a single cell of the T0 (control) treatment. Chromosome measurements in other strains were also obtained using a camera lucida.

\section{Tetrad analysis and pollen viability}

Tetrad analysis and pollen viability were assessed as described by Medina and Conagin (1964). The technique of Alexander (1980) was also used to estimate pollen viability in order to allow comparison between the results obtained with both techniques (Dafni, 1992).

Table 1 - Chromosome number (2n), pairing at diakinesis, tetrad normality and pollen viability (\%) in strains of Stevia rebaudiana (Bertoni) Bertoni.

\begin{tabular}{|c|c|c|c|c|c|}
\hline Access & Origin & $2 \mathrm{n}$ & Pairing at diakinesis & Tetrad normality (\%) & Pollen variability $(\%)$ \\
\hline Brasília F1 & CENARGEN/EMBRAPA & 22 & $11_{\text {II }}$ & 98 & 0 \\
\hline Maringá F1 & Maringá-PR & 22 & $11_{\text {II }}$ & 99 & 0 \\
\hline Canada F1 & Canada & 22 & $11_{\text {II }}$ & 96 & 0 \\
\hline T0 (control) & Maringá-PR & 22 & $11_{\text {II }}$ & 95 & 0 \\
\hline T5V1 & CENARGEN/EMBRAPA & 22 & $11_{\text {II }}$ & 96 & 0 \\
\hline T6V1 & CENARGEN/EMBRAPA & 22 & $11_{\text {II }}$ & 99 & 0 \\
\hline T6V3 & CENARGEN/EMBRAPA & 44 & $11_{\mathrm{IV}}$ & 80 & 0 \\
\hline T7V1 & CENARGEN/EMBRAPA & 33 & $11_{\text {III }}$ & 64.5 & 0 \\
\hline T8V1 & CENARGEN/EMBRAPA & 22 & $11_{\text {II }}$ & 93 & 0 \\
\hline T8V2 & CENARGEN/EMBRAPA & 22 & $11_{\text {II }}$ & 97.5 & 0 \\
\hline T9V1 & CENARGEN/EMBRAPA & 22 & $11_{\text {II }}$ & 98 & 0 \\
\hline
\end{tabular}


The total number of normal and abnormal tetrads per slide (approximately 1,000 tetrads from five floral buds) was used to estimate tetrad normality. Pollen viability was assessed for each strain by counting the number of viable and non-viable grains in 200 pollen grains per bud collected from five floral buds of different inflorescences. Each slide was prepared with the anthers of a single bud.

\section{Morphometric analysis}

The morphometric analysis focused on stomata size, pollen diameter, and on some vegetative (leaf size and plant height) and reproductive (inflorescences per plant) features.

The number and size of stomata were determined using the third leaf of the primary branch, from the apex down (Figure 1B), of plants from each strain cultivated in the field. The stomata were observed from the impressions made on a thin film of transparent cellulose wetted with acetone and applied to the adaxial surface of the leaf. Approximately 10 leaf impressions from 10 individuals of each strain were collected. To determine stomata size, 100 stomata from each leaf impression were drawn using a camera lucida, and their length and width then measured (Figure 1A). The stomata density was calculated by counting the stomata in five microscopic fields per slide using a $40 \mathrm{X}$ objective and a $10 \mathrm{X}$ ocular (area of $0.23 \mathrm{~mm}^{2}$ per field).

Pollen diameter was determined by drawning 100 pollen grains from each of five floral buds using a camera lucida (total of 500 pollen grains per strain). The height of all of the plants was measured (Figure 1B). Leaf size (length and width) was assessed using the first two leaves of the lowest secondary branch of each plant in all of the strains. The number of inflorescences was established using the second secondary branch, at the third tertiary branch of each plant (Figure 1B).

Variations in the measurements among plants of each strain were compared by calculating the coefficient of variation (CV\%). Variations between strains were assessed using ANOVA to determine whether there was a relationship between the level of ploidy and the parameters measured (pollen and stomata size, leaf size, plant height and number of inflorescences per branch). A value of $\mathrm{p}<0.05$ indicated significance.

\section{Results}

Almost all of the $S$. rebaudiana strains studied had $2 n=22$, except for two, which had $2 n=33$ and $2 n=44$ (Table 1, Figure 2). The karyotype of the T0 plants consisted of 11 pairs of chromosomes (six metacentrics, four submetacentrics and one acrocentric pair). The chromosomal measurements for the T6V3, T5V1 and T8V2 strains were similar (1.1-2.3 ìm). A satellite was observed on the short arm of the third pair of chromosomes.
Diakinesis was the only phase analyzed in meiosis. Pairing was $\mathrm{n}=11_{\text {II }}$ for all strains of $S$. rebaudiana, except for two, which had $\mathrm{n}=11_{\mathrm{III}}$ and $\mathrm{n}=11_{\mathrm{IV}}$, that corresponded to $2 \mathrm{n}=33$ and $2 \mathrm{n}=44$, respectively (Table 1 , Figure 2). The tetrad normality rate varied from $64.5 \%$ to $99 \%$ (Table 1). Abnormal tetrads generally had three but never four nuclei. The pollen of all strains was inviable (Table 1, Figure 2).

In the 12 strains examined, the stomata were $30-52 \mu \mathrm{m}$ long and $18-28 \mu \mathrm{m}$ wide, with a density of 12 to 22 stomata per unit area. The pollen diameter varied from 21.2 to $34 \mathrm{~m}$ (Table 2, Figure 2).

Morphometric analysis showed that plant height varied from 27.8 to $96.8 \mathrm{~cm}$, the number of inflorescences ranged from 5 to 22 (per unit), and leaf length and width ranged from 1.8 to $4.9 \mathrm{~cm}$ and from 0.6 to $2.24 \mathrm{~cm}$, respectively (Table 2).

The coefficients of variation for the features measured were: $1.64-2.77 \%$ and $1.69-5.30 \%$ for stomata length and width, respectively, $8.5-38.6 \%$ for pollen diameter, $8-41.1 \%$ for plant height, $23-51.9 \%$ for inflorescence number, and $11.1-30.7 \%$ and $13.8-32.4 \%$ for leaf length and width, respectively. Analysis of variance showed that all of the features quantified differed significantly among strains $(\mathrm{p} \leq 0.001)$ (Table 2).
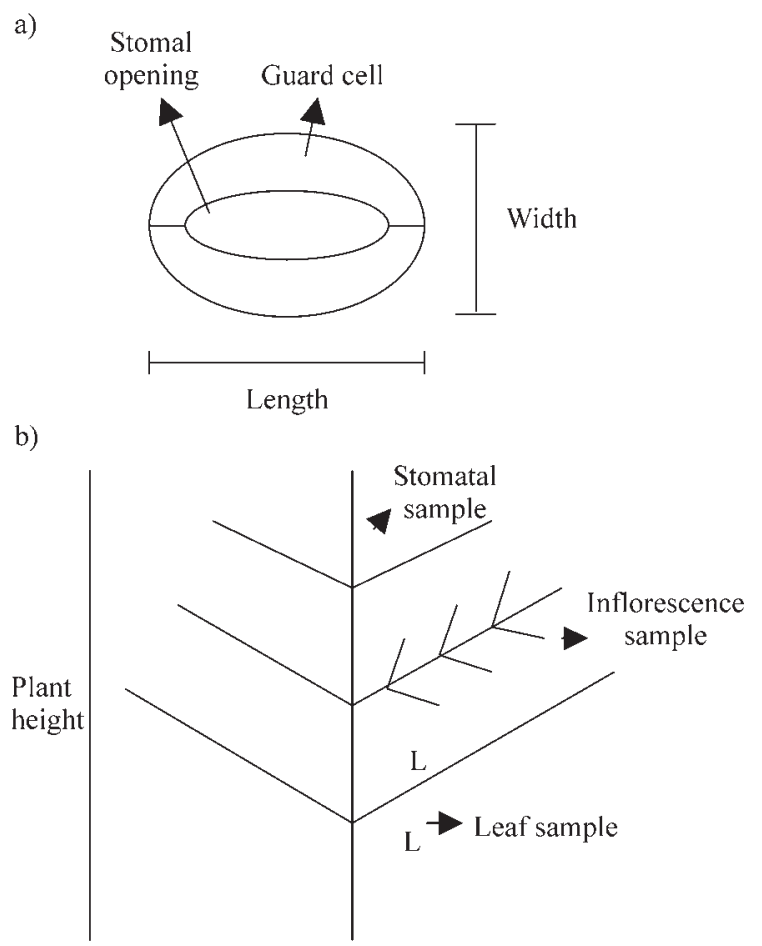

Figure 1 - a) Diagram of a stoma indicating the positions used to measure the length and width. b) Diagram of Stevia rebaudiana (Bertoni) Bertoni, indicating the location of the points of stomatal, leaf and inflorescence sampling and the procedure used to determine plant height $(\mathrm{L}=$ leaf). 

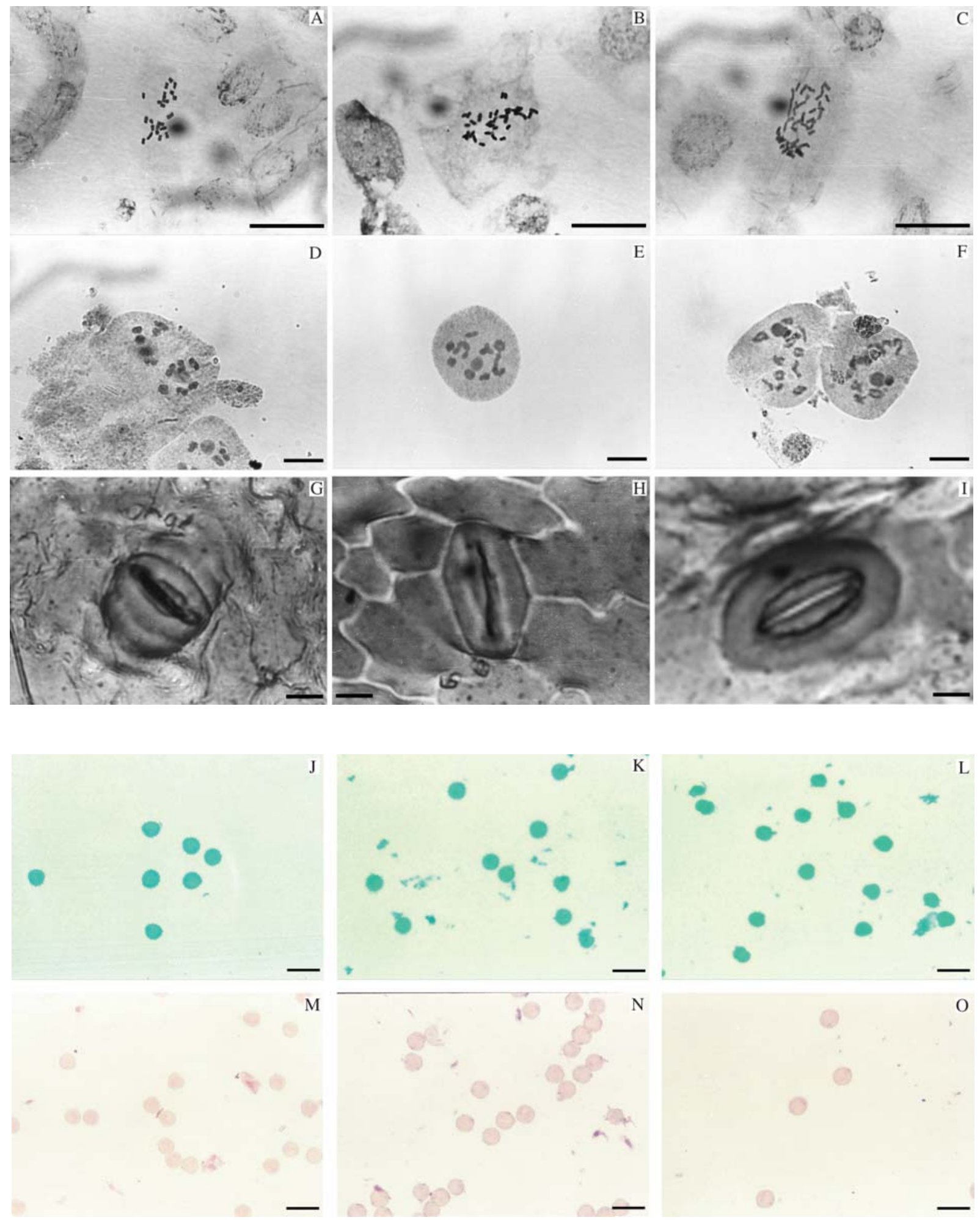

Figure 2 - Mitosis (A-C), meiosis (D-F), stoma (G-I) and pollen stained according to Alexander (J-L) or with acetic carmine (M-O) for strains of Stevia rebaudiana (Bertoni) Bertoni. A, D, G, J, M = Maringá F1 ( $\left.2 \mathrm{n}=22, \mathrm{n}=11_{\text {II }}\right), \mathrm{B}, \mathrm{E}, \mathrm{H}, \mathrm{K}, \mathrm{N}=\mathrm{T} 7 \mathrm{~V} 1\left(2 \mathrm{n}=33, \mathrm{n}=11_{\text {III }}\right)$ and C, F, I, L, O = T6V3 (2n = 44, $\left.\mathrm{n}=11_{\mathrm{IV}}\right) . \mathrm{N}=$ nucleolus. Bars $=10 \mu \mathrm{m}$ in A-F and $20 \mu \mathrm{m}$ in G-O. 


\section{Discussion}

The genus Stevia shows great variation in chromosome number. Although most reports indicate that $\mathrm{n}=11$ $(2 n=22)$, values of $2 n=24,33,34,44,48,66,70$ have also been observed (Darlington and Wylie, 1955; Bolkhoviskikh et al., 1969; Moore, 1973, 1974, 1977; Golblatt, 1981, 1984, 1985, 1988; Goldblatt and Johnson, 1990, 1991, 1996, 1998).

Galiano (1987) considered Stevia as a multibasic genus, with $\mathrm{x}=11, \mathrm{x}=12$ and $\mathrm{x}=17$, while Frederico et al. (1996) considered its basic chromosome number as $\mathrm{x}=11$. According to This variation reflects numerical (aneuploidy and polyploidy) and structural changes, mainly pericentric inversions (Frederico et al., 1996). Aneuploidy also occurs in Picris babylonica, a plant that belongs to the same family as Stevia (Malallah et al., 2001).

For $S$. rebaudiana, the chromosome number of $2 \mathrm{n}=22(\mathrm{n}=11)$ previously reported by Frederico et al. (1996) and Monteiro (1980, 1982) was confirmed here for various strains (Table 1). However, two strains had $2 \mathrm{n}=33$ and $2 n=44$, and represented triploid and tetraploid cytotypes, respectively (Table 1). For most strains, pairing at diakinesis was $n=11_{\text {II }}$, which agrees with the literature, while pairing at diakinesis for the triploid and tetraploid strains was $\mathrm{n}=11_{\text {III }}$ and $\mathrm{n}=11_{\mathrm{IV}}$, respectively (Table 1 ). This formation of multivalents suggested that these strains may have an autopolyploid origin.

Details of the chromosomal morphology of six Brazilian species of Stevia, including $S$. rebaudiana, were recently published by Frederico et al. (1996). The karyotypes were very similar in chromosome number $(2 n=22)$ and size $(1.0-2.4 \mu \mathrm{m})$. Most of the chromosomes were metacentric, with a variable number of submedian ones. Only $S$. ophryophylla and S. rebaudiana had a pair with a subterminal centromere (Frederico et al., 1996). These details of the chromosome size and centromere position were confirmed here for the T0 (control) strain. Chromosome lengths were similar in other strains with $2 \mathrm{n}=22$ (T5V1 and T8V2) or $2 n=44$ (T6V3). The presence of a nucleolus organizing region on the short arm of the third major chromosome pair (Frederico et al., 1996) was also confirmed for $S$. rebaudiana.

Different cytotypes or chromosomal races within the same species have been reported for various plants, such as Duguetia furfuraceae $(2 \mathrm{n}=16,24$ and 32) (Annonaceae) from the Brazilian cerrado (Morawetz, 1984). Some Gramineae have also been reported to have cytotypes with diploid and tetraploid individuals; tetraploids are often associated with asexual reproduction through agamospermy.

Unlike the above cytotypes which occur spontaneously in nature, the Stevia cytotypes analyzed here were obtained artificially by inducing polyploidy (Valois, 1992). Polyploidization was only confirmed in two treatments, T6 and T7, which corresponded to the lowest colchicine concentrations. Polyploidy is often induced in plants of economical interest in order to produce variability that can improve the yields (Allard, 1960). This approach has been applied to coffee (Cruz et al., 1993), orange (Romero and Aranda et al., 1997), Nicandra physaloides (Gupta and Roy, 1986) and Clitoria ternatea (Gandhi and Patil, 1997).

Attempts to induce polyploidy are not always successful and often lead to a small number of plants with chromosomal duplications. Seeds of Jatropha curcas (Euphorbiaceae) exposed to various concentrations of colchicine (Forni-Martins and Cruz, 1985) gave results similar to those obtained by Valois (1992) for $S$. rebaudiana. The plantlets of $J$. curcas showed various morphological changes and a very low survival rate (10 plants out of the 300 seeds used in the experiment). Only three of the surviving plants showed polyploidization.

Table 2 - Means $(\bar{x})$ and coefficients of variation (CV\%) for plant height, leaf length and width (in cm), inflorescence number (in units), stomal length and width, and pollen grain diameter (in $\mu \mathrm{m}$ ) in strains of Stevia rebaudiana (Bertoni) Bertoni grown at CPQBA/UNICAMP

\begin{tabular}{|c|c|c|c|c|c|c|c|c|c|c|c|c|c|c|}
\hline \multirow[t]{2}{*}{ Strains } & \multicolumn{2}{|c|}{$\begin{array}{r}\text { Leaf } \\
\text { length }\end{array}$} & \multicolumn{2}{|c|}{$\begin{array}{r}\text { Leaf } \\
\text { width }\end{array}$} & \multicolumn{2}{|c|}{$\begin{array}{l}\text { Inflorescence } \\
\text { number }\end{array}$} & \multicolumn{2}{|c|}{$\begin{array}{l}\text { Plant } \\
\text { height }\end{array}$} & \multicolumn{2}{|c|}{$\begin{array}{l}\text { Stomal } \\
\text { length }\end{array}$} & \multicolumn{2}{|c|}{$\begin{array}{l}\text { Stomal } \\
\text { width }\end{array}$} & \multicolumn{2}{|c|}{$\begin{array}{l}\text { Pollen grain } \\
\text { diameter }\end{array}$} \\
\hline & $\begin{array}{c}\bar{x} \\
(\mathrm{~cm})\end{array}$ & $\mathrm{CV} \%$ & $\begin{array}{c}\bar{x} \\
(\mathrm{~cm})\end{array}$ & $\mathrm{CV} \%$ & $\begin{array}{c}\bar{x} \\
\text { (units) }\end{array}$ & $\mathrm{CV} \%$ & $\begin{array}{c}\bar{x} \\
(\mathrm{~cm})\end{array}$ & $\mathrm{CV} \%$ & $\begin{array}{c}\bar{x} \\
(\mu \mathrm{m})\end{array}$ & $\mathrm{CV} \%$ & $\begin{array}{c}\bar{x} \\
(\mu \mathrm{m})\end{array}$ & $\mathrm{CV} \%$ & $\begin{array}{c}\bar{x} \\
(\mu \mathrm{m})\end{array}$ & $\mathrm{CV} \%$ \\
\hline Brasília F1 & 2.05 & 20 & 0.53 & 16.5 & 16.88 & 23.7 & 83.2 & 6.9 & 36 & 2.77 & 20 & 3.67 & 22.2 & 12.8 \\
\hline Maringá F1 & 2.60 & 11.7 & 0.98 & 28.9 & 16.58 & 33.5 & 88.2 & 23.4 & 36 & 2.75 & 20 & 3.0 & 23.8 & 12.1 \\
\hline Canada F1 & 2.44 & 15.4 & 0.55 & 29.9 & 22.2 & 44.4 & 70.4 & 8 & 34 & 2.16 & 20 & 2.89 & 23.2 & 11.7 \\
\hline T0 (control) & 1.83 & 23.1 & 0.60 & 13.8 & 17.57 & 35.6 & 86.6 & 17.5 & 34 & 2.18 & 20 & 2.69 & 22.6 & 17.5 \\
\hline T5V1 & 3.42 & 19.8 & 1.25 & 42.6 & 8.50 & 41.5 & 78.0 & 5.4 & 30 & 2.59 & 18 & 4.64 & 27.6 & 20.1 \\
\hline T6V1 & - & - & - & - & - & - & - & - & 34 & $1, .91$ & 20 & 3.39 & 24 & 8.5 \\
\hline T6V3 & 4.94 & 30.7 & 2.24 & 32.4 & 30.86 & 44.1 & 52.75 & 32.9 & 52 & 1.64 & 28 & 3.05 & 29 & 38.6 \\
\hline T7V1 & 2.41 & 30.5 & 1.10 & 29.5 & 5.30 & 51.9 & 27.80 & 38 & 40 & 2.08 & 24 & 3.97 & 34 & 12 \\
\hline T8V1 & 1.95 & 29.1 & 0.47 & 21.9 & 11.25 & 44.1 & 65.75 & 41.1 & 36 & 2.45 & 20 & 4.23 & 21.4 & 19.4 \\
\hline T8V2 & - & - & - & - & - & - & - & - & 36 & 2.34 & 20 & 4.15 & 21.2 & 13.3 \\
\hline T9V1 & 2.95 & 21.6 & 0.96 & 26.8 & 17.20 & 34.4 & 96.37 & 23.3 & 36 & 2.27 & 20 & 5.3 & 22.2 & 11.9 \\
\hline
\end{tabular}


Multivalents at diakinesis would be expected in autopolyploids, since the latter are derived from a single genome and result in three or four homologous sets of chromosomes in triploid and tetraploids, respectively (Stace, 1980).

Normal meiosis can be inferred from the pollen viability. Although pairing at diakinesis was normal, with the formation of bivalents in all diploids, in none of the $S$. rebaudiana strains studied was the pollen viable. High rates of tetrad normality ( $>93 \%$ ) were also observed in the diploid strains. The lowest tetrad normality rates were those of the tetraploid (80\%) and triploid (64.5\%) strains. Because of irregularities which produce unbalanced gametes during meiosis, polyploids with an odd number of chromosome sets have a high level of sterility (Lawrence, 1980).

The low tetrad normality rates and the lack of viable pollen in the triploid and tetraploid cytotypes may be related to the pairing of multivalents (tetravalents and trivalents) at diakinesis. Other meiotic anormalities, such as irregular chromosomal disjunction in anaphase, could also explain these results. However, as with the diploid cytotypes, the lack of viable pollen cannot necessarily be linked with regular pairing at diakinesis (bivalents) and high rates of tetrad normality.

Using the acetic carmine technique, Monteiro (1980) observed that in some diploid individuals of $S$. rebaudiana the pollen viability was $65 \%$, which differs from the results of the present study. This discrepancy may reflect how pollen viability tests are interpreted. Although pollen reacts in the acetic carmine technique, the staining is quite weak and may not be enough to characterize viable grains. For this reason, we also used the technique of Alexander (1980), which allowed a comparison between the results of the two tests and increased the reliability of our conclusions. This second technique, which produces a much greater difference in color between viable and inviable grains (red cytoplasmic staining for viable grains and green cell wall staining for inviable grains), also showed that there were no viable grains.

Our results on pollen viability are even less consistent when compared to the high tetrad normality rates (>93\%) of the diploid strains. Since the tetrad phase antecedes that of pollen, the difficulty in interpreting pollen viability remains. Indeed, staining techniques do not always allow pollen viability to be assessed as accurately as the true germination capacity under natural conditions or in appropriate environments (Dafni, 1992).

According to Forni-Martins et al. (1992), the analysis of sporogenesis allows the detection of irregularities that can lead to the formation of inviable gametes. In Peixotoa sp. (Malpighiaceae), the presence of trivalents is directly related to high pollen grain inviability and, consequently, to the probable formation of inviable seeds (Forni-Martins et al., 1992). Lopes et al. (2002) observed the formation of multivalents with low pollen viability $(40.6 \%)$ as well as considerable variation in pollen size in a species of Senecio (Asteraceae).

Stevia rebaudiana has light and dark achenes with the former being completely sterile. The fertility rate of dark achenes is 50\% (Monteiro, 1980). Agamospermy, i.e. the asexual formation of seeds (Lumaret, 1988), could explain the reproductive capacity of this species, even if one takes into account the total lack of viable pollen observed here. According to Mogie (1992), apomictic species are common in the Asteraceae, Rosaceae and Poaceae, which possess a "pre-adaptation" set that allows the development of apomictic embryos.

Grashoff (1974 apud Monteiro, 1980) and Monteiro (1980) reported agamospermy in $S$. rebaudiana. According to Monteiro (1980), the presence of apomixis in $S$. rebaudiana shown by embryological studies may be related to specific physiological and/or ecological factors. According to Grashoff (1974 apud Monteiro, 1980), sexual and apomictic plants of $S$. rebaudiana produce normal and malformed pollen, respectively.

Cytotypes (or chromosomal races) with diploid and tetraploid individuals have been reported for some Gramineae and are often associated with asexual seed reproduction, i.e. agamospermy (Burson, 1975). According to Stebbins (1971), other Asteraceae, such as Crepis, Taraxacum and Hieracium, also show apomixis. All of the agamospermic species in Taraxacum and Hieracium are polyploid, with a few of them having odd ploidy numbers and sometimes highly irregular meiosis (Stace, 1980). In the genus Parthenium, the apomictic species are also associated with polyploidy. Eupatorium and Ageratina (King et $a l ., 1977)$ contain sexual and apomictic species, the latter being characterized by irregular meiosis and inviable pollen.

According to Stebbins (1971), polyploid populations show considerable ecological, morphological and genetic differences compared to their corresponding diploids. A1though a higher ploidy number has been associated with larger pollen (Muller, 1979), this correlation is only consistent for autopolyploids (Stebbins, 1971). In some coffee (Boaventura et al., 1981) and cassava (Carvalho et al., 1999) plants with different chromosome numbers, there is a tendency for stomata cell size to increase with the level of ploidy.

Many domestic autopolyploid plants are larger than their corresponding diploids (Lawrence, 1980). Keeler and Davis (1999) noted differences in the size of Andropogon gerardii, a species with hexaploid $(2 \mathrm{n}=6 \mathrm{x}=60)$ and enneaploid $(2 n=9 x=90)$ cytotypes, in which the biggest individuals had the highest chromosome number. Because of the different plant sizes, the production of seeds per unit area was equivalent for both cytotypes, but was more efficient in hexaploids. The leaves in enneaploid plants were larger than in the hexaploid cytotype. 
The coefficients of variation $(\mathrm{CV} \%)$ for the features quantified here gave an idea of the variation involved (Gomes, 1978). The sample size may have influenced the CV\% since a sample of 1,000 pollen grains per strain, considered to be large, was used to analyze the pollen diameter and stomata size. Most of the strains had an intermediate CV\% (between $10 \%$ and 20\%) for pollen diameter, while all had a low $\mathrm{CV} \%(<10 \%)$ for stomata size. In contrast, the smallest sample size used for all of the other features (leaf size, plant height and inflorescence number) reflected the fact that there were few plants in the field (approximately 10 plants per strain), and meant that in most strains these parameters had high (20-30\%) or very high ( $>30 \%)$ coefficients of variation. A further complicating factor was that $S$. rebaudiana plants lose their leaves completely in the winter and only resprout in the spring. The inherent high genetic variability in vegetative features (such as plant size), flowering period and content of active principles, such as stevioside (Magalhães, 2000) and rebaudioside A (Stefanini and Rodrigues, 1999), also contributed to the high CVs.

ANOVA showed that among strains with different levels of ploidy, there was significant $(\mathrm{p} \leq 0.001)$ variation in all of the features quantified here. These significant morphological differences among the diploid, triploid and tetraploid strains meant that some features, especially pollen and stomata sizes, could be used to diagnose the level of ploidy much quicker and easier than chromosomal analysis.

There was a positive correlation between the size of the pollen or stomata and the level of ploidy, whereas this relationship was negative for plant size since diploids were larger than their corresponding autopolyploids. Compared to diploids, the tetraploid strain had larger leaves but there was no significant difference between the triploid and diploid strains. Similarly, the triploid and tetraploid strains had lower and higher numbers of inflorescences, respectively, compared to diploid plants.

The results obtained here open new possibilities for genetic breeding programs of $S$. rebaudiana since polyploid individuals may have a higher content of stevioside than diploid plants and the selection of plants for commercial prodution could possibly increase the level of these compounds. Despite the male sterility present in various strains of $S$. rebaudiana, agamospermy (Monteiro, 1980) could ensure a sufficient seed yield to allow the genetic breeding of this species.

\section{Acknowledgements}

V.M.O. was supported by a scholarship from FAPESP (Fundação de Amparo à Pesquisa do Estado de São Paulo).

\section{References}

Alexander MP (1980) A versatile stain for pollen, fungi, yeast and bacteria. Stain Technol 55:13-18.
Allard RW (1960) Principles of Plant Beeding. John Wiley \& Sons, Inc., New York, 485 pp.

Boaventura YMS, Medina DM, Vieira MJFR and Arruda HV (1981) Número de cloroplastos e nível de ploidia em espécies de Coffea L. Rev Bras Bot 4:15-21.

Bolkhoviskikh Z, Grif V, Matvejeva T and Zakharyeva HV (1969) Chromosome number of flowering plants. VL Komarov Botanical Institute, Academy of Sciences of the USSR, Moscou, $926 \mathrm{pp}$.

Burson BL (1975) Cytology of some apomitic Paspalum species. Crop Sci 15:229-232.

Carvalho R, Guerra M and Carvalho PCL (1999) Occurrence of spontaneous triploids in Manihot esculenta Crantz. Cytologia 64:137-140.

Cruz ND, Boaventura MS, Conagin CHTM, Dutilh JHA, ForniMartins ER, Medina DM, Mendes AJT, Pierozzi NI and Pinto-Maglio CAF (1993) Cinqüenta e Três Anos de Pesquisa em Citogenética Vegetal. Documents IAC, n. 27. 60 $\mathrm{pp}$.

Dafni A (1992) Pollination Ecology: A Practical Approach. 1st edition. Oxford Universty Press, Oxford, $250 \mathrm{pp}$.

Darlington C and Wylie AP (1955) Chromosome Atlas of Flowering Plants. 2nd edition. George Allen and Unwin Ltd., London, $519 \mathrm{pp}$.

Felippe GM, Lucas NMC, Behar L and Oliveira MAC (1971) Observações a respeito da germinação de Stevia rebaudiana Bert. Hoehnea 1:81-93.

Forni-Martins ER and Cruz ND (1985) Dados preliminares sobre indução de poliploidia em Jatropha curcas (Euphorbiaceae). Congresso da Sociedade Botânica de São Paulo, V. Botucatu. Resumos: p 167.

Forni-Martins ER, Pinto-Maglio CAF and Cruz ND (1992) Biologia da reprodução em plantas de cerrado: Microesporogênese. Anais $8^{\circ}$ Congresso SBSP, pp 77-82.

Frederico AP, Ruas PM, Marin-Morales MA, Ruas CF and Nakajima JN (1996) Chomosome studies in some Stevia Cav. (Compositae) species from southern Brazil. Rev Bras Genet 19:605-609.

Galiano NG (1987) Estudios cromosomicos en especies argentinas de Stevia (Compositae). Darwiniana 28:311-315.

Gandhi S and Patil VP (1997) Colchicine-induced autotetraploidy in Clitoria ternatea L. Cytologia 62:13-18.

Gentry AH (1996) A Field Guide of the Families and Genera of Woody Plants of Northwest South America (Colombia, Ecuador, Peru) with Supplementary Notes on Herbaceus Taxa. The University of Chicago Press, Chicago, 895 pp.

Goldblatt P (1981) Index to Plant Chromosome Numbers 1975 1978. Monographs in Systematic Botany from the Missouri Botanical Garden. v. 5. Missouri Botanical Garden, St. Louis, $553 \mathrm{pp}$.

Goldblatt P (1984) Index to Plant Chromosome Numbers 19791981. Monographs in Systematic Botany from the Missouri Botanical Garden. Vol. 8. Missouri Botanical Garden, St. Louis, $432 \mathrm{pp}$.

Goldblatt P (1985) Index to Plant Chromosome Numbers 19821983. Monographs in Systematic Botany from the Missouri Botanical Garden. v. 13. Missouri Botanical Garden, St. Louis, $224 \mathrm{pp}$.

Goldblatt P (1988) Index to Plant Chromosome Numbers 19841985. Monographs in Systematic Botany from the Missouri 
Botanical Garden. v. 23. Missouri Botanical Garden, St. Louis, 264 pp.

Goldblatt P and Johnson DE (1990) Index to Plant Chromosome Numbers 1986-1987. Monographs in Systematic Botany from the Missouri Botanical Garden. v. 30. Missouri Botanical Garden, St. Louis, 242 pp.

Goldblatt P and Johnson DE (1991) Index to Plant Chromosome Numbers 1988-1989. Monographs in Systematic Botany from the Missouri Botanical Garden. v. 40. Missouri Botanical Garden, St. Louis, 238 pp.

Goldblatt P and Johnson DE (1996) Index to plant chromosome numbers 1992-1993. Monographs in Systematic Botany from the Missouri Botanical Garden. v. 58. Missouri Botanical Garden, St. Louis, 276 pp.

Goldblatt P and Johnson DE (1998) Index to Plant Chromosome Numbers 1994-1995. Monographs in Systematic Botany from the Missouri Botanical Garden. v. 69. Missouri Botanical Garden, St. Louis, 208 pp.

Gomes FP (1978) Curso de Estatística Experimental. 8th edition. Nobel, São Paulo, 258 pp.

Guerra M (1983) O uso de Giemsa em citogenética vegetal-comparação entre a coloração simples e o bandeamento. Ciênc Cult 35:190-193.

Guerra M (1988) Introdução à Citogenética Vegetal. Editora Guanabara, Rio de Janeiro, 142 pp.

Gupta SK and Roy SK (1986) Induced colchiploidy in Nicandra physaloides. Cytologia 51:319-324.

Keeler HK and Davis GA (1999) Comparison of commom cytotypes of Andropogon gerardii (Andropogoneae, Poaceae). Am Bot 86:974-979.

King RM, Kyhos DW, Powell AM, Raven PH and Robison H (1977) Chromosome numbers in Compositae XIII. Eupatorieae. Ann Miss Bot Gard 63:862-888.

King RM and Robinson H (1987) The genera of the Eupatoriae (Asteraceae). Missouri Botanical Garden Library, Saint Louis, pp 1-180.

Lawrence WJC (1980) Melhoramento Genético Vegetal. v. 6. EDUSP, São Paulo, 75 pp.

Lopes MG, Wulff AF and Xifreda CC (2002) Chromosome contribution to Andean polyploid species of Senecio (Asteraceae), from Argentina. Caryologia 55:27-35.

Lumaret R (1988) Adaptive strategies and ploidy levels. Acta Oeco 9:83-93.

Magalhães PM (2000) Agrotecnología para el cultivo de estévia o hierba dulce. In: Fundamentos de Agrotecnología de Cultivo de Plantas Medicinales Iberoamericanas. CYTED-CAB, Bogotá, pp 441-450.

Malallah GA, Attia TA and Masood M (2001) Aneuploidy in wild Picris babylonica (Asteraceae) in Kuwait. Cytologia 66:241-246.

Medina DM and Conagin CHTM (1964) Técnica Citológica. Publicação 2610. Instituto Agronômico de Campinas, Campinas, $107 \mathrm{pp}$.

Mogie M (1992) The Evolution of Assexual Reproduction in Plants. Chapman \& Hall, London, 265 pp.

Monteiro R (1980) Taxonomia e biologia da reprodução de Stevia rebaudiana Bert. Masters Thesis, Universidade Estadual de Campinas, Campinas.

Monteiro R (1982) Estudos cromossômicos em Stevia rebaudiana-Série Multiaristatae no Brasil. Rev Bras Bot 5:5-15.

Moore RJ (ed) 1973. Index to Plant Chromosome Numbers 1967-1971. Regnum Veg 90:1-539.

Moore RJ (ed) (1974) Index to Plant Chromosome Numbers 1972. Regnum Veg 91:1-108.

Moore RJ (ed) (1977) Index to Plant Chromosome Numbers 1973-1974. Regnum Veg 96:1-257.

Morawetz W (1984) Karyological races and ecology of the Brazilian Duguetia furfuracea as compared with Xylopia aromatica (Annonaceae). Flora 175:195-209.

Muller J (1979) Form and function in angiosperm pollen. Ann Miss Bot Gard 66: 593-692.

Randi AM (1980) Germinação de Stevia rebaudiana Bert. Masters Thesis, Universidade Estadual de Campinas, Campinas.

Robinson H and King RM (1977) Eupatoriae-systematic review. In: Heywood VH, Harbone JB and Turner BL (eds) The Biology and Chemistry of the Compositae. v 1. Academic Press Inc., London, pp 286-437.

Romero-Aranda R, Bondada BR, Syvertsen JP and Grosser JW (1997) Leaf characteristics and net gas exchange of diploid and autotetraploid citrus. Ann Bot 79:153-160.

Stace CA (1980) Plant Taxonomy and Biosystematics. Edward Arnold, London, 264 pp.

Stebbins GL (1971) Chromosome Evolution in Higher Plants. Edward Arnold, London, $216 \mathrm{pp}$.

Stefanini MB and Rodrigues SD (1999) Influência do ácido giberélico na produção de biomassa em Stevia rebaudiana (Bert.) Bertoni. Rev Bras P1 Med 1:35-43.

Valois ACC (1992) Stevia rebaudiana Bert: uma alternativa econômica. Comunicado Técnico, CENARGEN, 13:1-13.

Editor Associado: Yatiyo Yonenaga-Yassuda 